THE JOURNAL OF TEACHING ENGLISH FOR SPECIFIC AND ACADEMIC PURPOSES Vol. 8, No 3, 2020, pp. 249-263

UDC: 378.147:811.111 https://doi.org/10.22190/JTESAP2003249M

\title{
CHALLENGES IN TEACHING ENGLISH FOR SPECIFIC PURPOSES IN ESTONIAN UNIVERSITIES
}

\author{
Merilyn Meristo, Francisco Javier López Arias \\ Tallinn University, Estonia \\ E-mail: merilyn.meristo@tlu.ee
}

\begin{abstract}
Due to the growing importance of globalization, the English language has acquired an even more influential role, and at the tertiary educational level it has provoked the necessity of teaching not just general English, but also English for Specific Purposes $(E S P)$, which meets the demands of students' field of study. Moreover, the preparation of undergraduate students for both entering the labour market or continuing their academic path has prioritized the significance of ESP. This paper aims to investigate how ESP teachers working in Estonian state-funded HEI with General English teaching background perceive their work in the field of ESP. Specifically, this abductive qualitative research seeks to obtain a deeper insight into the challenges posed by teaching ESP and to detect problematic issues to better support university teachers to improve their work. The results highlight three major challenges: coping with changes through the lenses of professionalism; insufficient collaboration, and instability in conducting ESP courses.
\end{abstract}

Key words: Cooperation, English for specific purposes, professionalism, university teachers challenges

\section{INTRODUCTION}

In Estonia, the internationalization of the workplace has accelerated since the country joined the European Union on January $1^{\text {st }}$, 2004, impacted by the implementation of the free movement of citizens among member states. In many international working environments located across Estonia, most professional and interpersonal communication among employees is usually conducted in English, in line with its status as an international lingua franca, and the use of the Estonian language seems to be, at best, variable and irregular. However, this shift in workplace culture has presented some challenges for all the actors involved, with the most obvious, and yet, crucial, being the difficulty for workers to carry out their duties in a language that is not their native one. Their knowledge of English, traditionally grounded in General English courseswith a lack of focus on specialized environments and professional settings that it traditionally entails, has seldom provided them with enough language skills to develop their professional careers as efficiently and productively, as it could have been expected with the subsequent negative impact that lost time and communication breakdowns have on their companies' workflow (Ufier 2014).

Higher education institutions across Estonia have noticed this divergence between the teaching of General English and the professional use that migrating students make of it, and, as a result, they are starting to take steps to narrow this gap by refocusing their English courses on providing a working knowledge of English in professional spheres as

Submitted September $4^{\text {th }}, 2020$, accepted for publication October $17^{\text {th }}, 2020$ 
well as in the personal field. This trend is not exclusive to Estonia, and the very noticeable increase in academia related to English for Specific Purposes (ESP) in the last decade is a direct consequence of it (cf. Leonardi 2015, Rackevičienè et al. 2019, Stojković et al. 2015). Estonian higher education institutions have begun this refocusing by implementing new ESP courses designed, among other things, to prepare students, language-wise, for the European-wide labour market they now have access to. Of course, this has brought new challenges to every stakeholder involved - teachers, students and the institutions themselves. The challenges posed by ESP teaching and learning have been thoroughly studied over the last two decades, but there has never been an exploration of these issues on the Estonian national level.

This paper aims to start that exploration by taking a closer look at one of those stakeholders, the ESP teachers in Estonia. Without any previous training on teaching and learning processes specific to ESP, most of them have transitioned from teaching General English and have had to transform their practices and methodologies by themselves while juggling, at the same time, the instability caused by the introduction of a reformed legal basis affecting the Estonian Higher Education system, the trial and error processes that always appears when a new system is introduced, and the changes that the widespread introduction of a new ESP environment caused on their job description and on their selfperception (Meristo 2020). In order to do so, interviews with Estonian ESP teachers from several higher education institutions have been conducted and analysed though a qualitative approach based on an abductive model. This paper is grounded in a theoretical framework heavily based on Hutchinson and Waters (1987) and further research emerging from their ideas. Our goal is to find out what kind of challenges and difficulties they have faced during the transition from General English to ESP teaching, and how they assess their own status and self-perception, and whether this assessment is consistent, and if so, how much according to our selected theoretical model. Gaining deeper insight into ESP teachers' experiences will inform stakeholders and employees responsible for managing ESP courses to better plan and organise their work in order to reduce the tension and support the teachers and their working environment. This study, conducted in the four biggest Estonian state-funded HEI might thus as well offer an interesting insight to the international audience.

\section{THEORETICAL FRAMEWORK}

Over three decades ago, in their seminal English for Specific Purposes: A Learningcentred Approach, Hutchinson and Waters $(1987,158)$ described certain challenges that many ESP teachers face over their careers. Since Hutchinson and Waters' book, ESP has experienced a great increase in the amount of research carried out into it, and in its public awareness. Nonetheless, this research has been uneven: the spotlight has been mostly put on the methodological side, while the elaboration of actual specialized classroom materials has been relatively neglected, or as Belcher $(2013,544)$ puts it: "It is no surprise that ESP professional education has not been a popular research topic, though calls for the development of more instruction in specific-purpose areas, such as Medical English, are not uncommon". This disparity has introduced new challenges for ESP teachers and students. However, the challenges introduced by Hutchinson and Waters (1987) seem very relevant even today. According to them, these issues can be grouped 
into three main categories: 1 . The lack of an ESP orthodoxy to provide a ready-made guide; 2 . The new realms of knowledge the ESP teacher has to cope with; 3 . The change in status of English Language Teaching. The following will look into these categories.

\subsection{The lack of an ESP orthodoxy to provide a ready-made guide}

The reason behind this challenge is the sudden and constant changes in the orientation of ESP teaching as regards its purpose and effectivity. The most evident manifestation is the conflict between the use of authentic materials vs. constructed ones as the most appropriate means of helping the student's learning process. Woodrow (2017) highlights the importance of the role of authentic materials in the ESP classroom and that these materials should be selected in cooperation with stakeholders in the field (38) or even with students (56). Yet, Anthony (2018) argues that using authentic material can be one of the most challenging tasks in the light of its difficultness and context. The most evident one is the lack of teaching materials for ESP, especially regarding fields outside of technology, law or business (Franceschi 2015, Kardaleska and Nedelkoska 2017). Currently, it is a widely accepted tenet of teaching methodologies that catering to the individual needs of each student is paramount as regards the optimization of their learning outcomes, but the main consequence of the lack of availability of ready-made materials is that teachers have to spend copious amounts of time elaborating their own, usually almost from scratch (Charles 2018, Lenard and Lenard 2018, Woodrow 2017). However, there are ESP coursebooks available in the market which often do not satisfy the students' needs as they are not stimulating enough for students' engagement because of the risk of being tedious (Tomlinson 2020a), i.e. during the university courses students learn subjects related to their study area and acquire specific knowledge and skills through extensive reading materials. An ESP course is expected to cover the terminology of their discipline, by offering it through texts too generic for their area, coursebooks do not actually offer any new information and may undermine their enthusiasm to engage into language learning. Furthermore, Tomlinson (2020b) warns about the lack of human approach in ready-made ESP materials, which are supposed to be efficient and quick, yet deprived of a personal dimension which might facilitate the contextualisation of acquired materials. Yet, maintaining students' interest towards learning is a teacher's priority (Coxhead 2018). According to Anthony (2018) the choice of materials to be used in the classroom is the biggest challenge. Moreover, even if there are materials available in a particular ESP field, there is a need to adapt them (Hyon 2018, Kithulgoda and Mendis 2020, Noguera-Díaz and Pérez-Paredes 2019, Woodrow 2017). Adapting materials to better match students' needs can only be conducted if the students' needs have been identified. Many researchers consider needs analysis of utmost importance to be conducted prior to designing an ESP course (Anthony 2018, Basturkmen 2014, Hyon 2018, Flowerdew 2012, Woodrow 2017). This suggestion cannot be underestimated. Anthony (2017) draws attention to a mismatch between learning objectives and stakeholders' actual needs. That mismatch could be avoided by conducting a detailed needs analysis. Identifying target needs can be challenging because different stakeholders with different expectations and views are involved (Hyon 2018). For instance, in Business English, in order to create a significant goal-set of ESP training, the teacher has to "analyse national economic goals, identify industry sector/business needs, review the education/training available, present a business case for English communication skills in 
the workforce, and understand the related advantages and responsibilities of multinational corporations for the growth and competitiveness of the economic stakeholders" (Stojkovic et al. 2015, 256).

\subsection{The new realms of knowledge the ESP teacher has to cope with}

As Kim et al. (2018) describes it, these are the difficulties teachers face when dealing with technical vocabulary related to academic areas alien to their lifelong fields of study. While specialized in foreign language teaching and general English teaching methodologies, ESP teachers need an academic knowledge of the terminology, the concepts and the processes related to the field they are teaching ESP for (Coxhead 2018, Woodrow 2017). This is often a challenge to ESP teachers, as they lack content knowledge ( $\mathrm{Li}$ and Flowerdew 2020, Woodrow 2017). In addition, there are differences in methodologies when compared to General English. For example, in ESP there is a greater focus on teaching 'Genre', i.e. communicative events (Paltridge 2014). Anthony (2018) suggests that ESP teachers cooperate with subject specialists to receive their input for the course design as well as their feedback on the results. He adds that the importance of collaboration emerges especially in the situation where the ESP teacher is not a subject specialist and lacks knowledge in the field. Collaboration involves not only subject specialists, but learners who can give input concerning the content of the course. The learners might already be experienced in the field and give more insight on the target community, thus bringing valuable knowledge to the classroom. However, in reality, collaboration between ESP teachers and subject specialists remains scarce, even within the same institution, as the epistemological and ontological background of both parts may create difficulties in understanding each other (Woodrow 2017). Furthermore, Norton (2018) warns about 'Pedagogic solitude', that some ESP teachers find themselves in, and highlights the need for a support network. As mentioned, it is possible to involve students in course design and let them guide the vocabulary teaching and learning process (Woodrow 2017, 56). However, this student-centre instruction, where the teacher should play a facilitator role, usually becomes stunted, as the teacher does not have enough knowledge to guide, check, and expand on the middle and final stages of the learning process, usually devoted to the deep and specialized parts of the field. Moreover, especially in the first stages of Tertiary Education, the student may not possess enough knowledge to actually be able to guide his own learning process without heavy teacher input, which, in turn, has a deep impact on student attitudes towards ESP (Laanemaa 2015). A study carried out by SlavicaČepon (2016, 188-198) has found out that one of the reasons why students experience anxiety during practicing speaking skills in the ESP classroom is "a lack of knowledge of the carrier content", defining 'carrier content' as "the specialist subject matter relating to a certain discipline".

\subsection{The change in status of English Language Teaching}

The change in status has been triggered by the transition from a subject in its own right to being a service industry subordinated to other specialities. Hutchinson and Waters (1987) explain the changes in status modification by situational-contextual factors, which remain quite relevant (low priority in timetabling; little contact with subject teachers as well as with colleagues in the ESP field). While Hyon (2018) argues that ESP teachers are often 'practitioners' who do research in the field of ESP (5), it is a common situation that ESP 
teachers are recruited as teaching-only staff who are not engaged in research (Lehtonen 2018). Furthermore, Stewart (2018) draws attention to the fact that ESP teachers experience concerns about their professional status. Their work might be regarded as second-rate by faculty members and ESP teachers are not considered as equal colleagues, their contribution becomes marginalized in the eyes of their colleagues. Another emerging issue is the increasing workload of ESP teachers as most materials need to be compiled and designed according to each student group and their needs (Hyon 2018). Woodrow (2017) informs about ESP teachers facing difficulties in adopting research-informed practice which might be a consequence of the heavy workload. Given the real-life situation, conducting research in the field might be too demanding (Hall 2012).

The above described challenges may put increasing pressure and tension on ESP teachers and their coping with demanding working conditions is reflected by an individual process, affecting their physical and psychological well-being (Lazarus 1993). There are several identified coping strategies that are relevant in the context of a working environment: problem-focused, emotion-focused, and avoidance-orientated coping strategies (Lazarus 1993, Sears, Urizar and Evans 2000). The personal choice of a coping strategy affects the teacher's well-being: an emotion-focused strategy might lead to depression, while a problem-focused strategy might promote feelings of self-efficacy.

To conclude on a positive note, regardless the challenges ESP teachers face daily, a learner's perspective demonstrates that ESP students are motivated by the prospect of advancing their professional careers within international and multicultural environments (Bakić-Mirić and Gaipov 2015, Koltai 2012), and they appreciate ESP courses as good academic preparation for their professional career (Arnó-Macià et al. 2020).

\section{ESP WITHIN THE ESTONIAN EDUCATIONAL SYSTEM}

\section{Secondary Schools}

The Estonian school system is characterized by providing each educational centre with considerable freedom to shape their own curriculum. In addition to the compulsory national curricula, some provisions in the education laws have been included, allowing schools to offer additional courses in any field of their choice. More often than not, the decisions on which additional courses to offer are based upon the particular characteristics of the given school and upon its specialization at the secondary school level. Three different specializations recurrently appear, one of the most popular ones being foreign languages and/or focusing on different aspects of the English language. These specializations usually compose of ESP courses as well. However, they are mostly limited to Business English, followed by British Literature and Translation Studies.

\section{Universities}

There are 6 state-funded public universities in Estonia, of which four ${ }^{1}$ have a history of teaching ESP that can be traced back for several decades. However, the initial extent of ESP courses was limited to certain academic fields, such as Health and Sport Sciences (with the exception of Medicine), Law and Business. Over the years, further disciplines

${ }^{1}$ Estonian University of Life Sciences, Tallinn University, Tallinn University of Technology and Tartu University 
have been added to the ESP fold, including, but not limited to, Info-technology, Engineering, Life Sciences or Social Sciences. In addition, state-funded institutions of applied sciences have enlarged this list by offering courses of ESP on Aviation, ESP for the Military, and ESP for Police Forces.

Despite the fact that ESP courses are not a novelty in Estonia, they became a widely spread phenomenon at Estonian universities, in the form of compulsory courses during the last six years. The motives for such a curriculum change have been similar in all universities - to enhance students English language skills to be able to read scientific literature in their field. As a result, in the majority of the offered degrees, achieving graduation requires passing a mandatory ESP course in their study area. For most disciplines, ESP courses at B2 or C1 level (as defined by the $\mathrm{CEFR}^{2}$ ), as well as Academic English at C1.2 level are offered. Every student deemed as required to complete an ESP course is expected to take a placement test after enrolment. Another option is to provide a proof of proficiency by means of an internationally recognized exam certificate (e.g. IELTS, TOEFL, $\mathrm{CAE}^{3}$ ) issued not earlier than 2 years before the start of the studies. Students with lower language levels are provided with courses at A2, B1.1 and B1.2 level in order facilitate reaching a proficiency level sufficient to allow them to take part in the compulsory ESP course.

Another aspect specific to Estonian universities is the combination of different disciplines into the same ESP group of students of related academic field (e.g. Biology and Environmental Management; or Geography, Geology and Environmental Technology; or Media, Journalism and Film; or Public Administration and Political Sciences). The reason for this development is the rather small number of students representing each discipline at each language level. Although this does prove to be a demanding task for ESP teachers, and once the previously compiled materials have proven adequate for reuse with minimal adaptation, the amalgamation of disciplines has achieved a relative stability.

\section{Methodology}

This study sets out to understand how ESP teachers with a General English teaching background perceive their work in the field of ESP. Specifically, the research seeks to obtain a deeper insight into the challenges posed by teaching ESP and to detect problematic issues to better support university teachers to improve their work. The research question central to the study was formulated as "How do ESP teachers perceive their work in the field of ESP?" The focus of this qualitative study is on the teachers' personal experiences in light of their sustained careers in teaching English. We focus not on factual events, but namely on personal experiences and the highly subjective meanings given to them. The qualitative research process was guided by an abductive approach. In abduction, researchers examine how the data is supported by existing theories or to the contrary, how the data may suggest modifications in theories by, for example, combining and reshaping old ideas (Kennedy and Thornberg 2018). "Pre-existing theories are used as a source of inspiration, and identification and interpretation of patterns" (Alvesson and Sköldberg 2008, as cited in Kennedy and Thornberg 2018, 52).

\footnotetext{
${ }^{2}$ CEFR: Common European Framework of Reference for Languages

3 The International English Language Testing System (IELTS), Test of English as a Foreign Language (TOEFL), Cambridge Assessment English (CAE)
} 


\subsection{Participants}

The sample was formed of 13 English teachers working in four different state-funded HEI of Estonia, two in Tallinn and two in Tartu. Convenience sampling was applied and the participants were contacted personally. All who agreed to participate were female (age between 26-60 years), with an average teaching experience in HEI of 20 years in General English and 5 years in ESP.

\subsection{Data collection}

In order to answer the research question, 13 semi-structured interviews were conducted with ESP teachers from four Estonian state-funded public universities. The duration of each interview was approximately 45 minutes. The teachers were asked to describe their experiences in teaching ESP. The interviews were conducted both in Estonian and in English depending on the preference of the interviewee. The participation was voluntary and no personal delicate information was asked.

\subsection{Data analysis}

The data analysis was carried out according to content analysis (Cohen et al. 2007). All experiences - positive, negative and neutral - were extracted from the interviews. Every extraction was assigned a keyword (a code) that described it best. Those keywords carrying similar meanings were grouped into broader categories. A close analysis of the interviews rendered 3 main categories that we later identified as challenges: professionalism, cooperation and stability. E.g. 'professional training', 'lack of experience', 'professional career' formed the category "PROFESSIONALISM"; 'sharing materials', 'discussing methodology together', 'meetings about ESP assessment' formed the category "COOPERATION"; and 'reusing the materials', 'same ESP field every year' formed the category "STABILITY". The next step was comparing the categories with existing theory

\section{Results}

A close analysis of the responses in the interviews has suggested that there are three main axes of challenges that ESP teachers in Estonia have to face.

\section{$1^{\text {st }}$ Challenge - Professionalism}

The interviewees expressed several opinions which fell into this category. Firstly, readiness to adapt to new professional situations:

I have worked as an English teacher my whole life, but always teaching General English. 2 years ago I started teaching ESP courses. First, I objected to this idea, as I have not received any training for that, but then I realised that it's me who is responsible for my own professional training. I accepted the challenge and I haven't regretted it. (Elsa)

I prepare all my materials myself, although I know there are other teachers in the same ESP field. I could ask them, but I don't feel comfortable as if I am not able to manage my own courses. (Tina) 
Elsa's opinion as an example here, reflects the development of her feelings from negative into final positive ones. She admits that professional development is an essential part of being a teacher, and that it is the teacher's responsibility to be professionally updated and complete the training available to her. On the contrary, Tina displays a sense of inadequacy and lack of confidence when it comes to asking for advicewhich creates for her a sense of false shame which in her opinion could be interpreted as a sign of beingunprofessional. However, the feeling of not being professional is not transmitted to other people, i.e. it is only perceived intrinsically towards oneself.

Secondly, the choice of a coping strategy, which directly reveals how the ESP teachers perceives the problem (changes): Is it solvable? Or is the teacher not willing to put any effort into it?

I was not happy when I realised that I had no choice but to accept teaching ESP courses. I had no experience in this field. I am not that young anymore and would honestly prefer the daily routine I am used to have. (Kate)

For example, Kate expresses a rather strong objection. She admits not being experienced in ESP, yet she shows confidence in what she has been doing for many years. In her interview, Kate does not show any evidence of a problem-focused coping pattern, on the contrary, she sees the situation as frustrating, but she remains passive towards it.

Thirdly, the topic of career expectations emerged. Kelly, as an example, perceives changes as a possibility to enhance her professional path:

I had no preferences in courses that I was about to teach. I like changes and I hate routine. Besides, I'm sure that courses with new content add new value to my professional career. (Kelly)

This challenge - Professionalism - is mostly related to the perceived lack of knowledge and professional training for the teaching of ESP courses. Both Elsa and Kate show some lack of confidence in themselves, but the way they cope with the situation is different. Elsa finds the strength in herself and develops further, whilst Kate remains emotional. Elsa performs problem-focused coping strategy, i.e. she makes task-oriented efforts to solve the problem which in turn strengthens her perceptions of self-efficacy, while Kate refers to an emotionoriented coping strategy through self-preoccupation and emotional reactions and the problem remains rather unsolvable to her (Lazarus 1993, Sears, Urizar and Evans 2000). Kelly does not need any coping strategy as she does not see the situation as a problem, but rather as an opportunity for her.

\section{$2^{\text {nd }}$ Challenge - Cooperation}

This challenge is described by the following ideas which were expressed during the interviews. Firstly, sharing materials with colleagues which is surprisingly ineffective and passive.

I would gladly share my materials and give recommendations if anyone asked.

(Kate)

I have tried to use the materials [ESP] of my colleague, but I find it difficult to use them. We do have different working methods, therefore only sharing some relevant texts could be useful, though I prefer choosing materials together with students. (Megan) 
All given examples imply that the cooperation with colleagues is limited and mostly due to a personal choice. Either there is a passive readiness (Kate) or a rather rigid choice of individual methods which leaves no room for experimenting with colleagues' propositions (Megan).

Secondly, the interviews showed a distinction between sharing materials and discussing methodology. The latter is seen a true form of collaboration which could take place among very good and valued colleagues.

My colleague and I, we share everything we find as suitable materials for ESP as there are no ready-made books. We've been working together for many years and we have always discussed how to better deal with obstacles and different issues. (Mary)

Mary's example is illustrative of teachers' opinions. There were others with similar experience that colleagues who have become friends or with who there is a long history of working together are the ones to collaborate with. Shared training sessions and meetings join academic staff members.

Thirdly, a separate category as 'Meetings about ESP assessment' came forth.

I found very useful all kinds of training in a situation where none of us had been specifically trained for ESP teaching and where we could openly share our experiences. Trainings about assessment, for example. (Elsa)

We sometimes worked in tandem-pairs to validate our grading. To reach upon an agreement, it took some time in meetings. (Jane)

Elsa and Jane's statements reflect the need for organised meetings, which could be in the form of training or a more informal meeting as long as it is guided by another professional or even by a particular topic. It suggests that meetings should have a certain objective so that they could be called as a part of collaborative activity (Wenger et al. 2002).

\section{$3^{\text {rd }}$ Challenge - Stability}

'Stability' emerged during the interviews through several viewpoints. Firstly, the idea about reusing the materials surfaced repeatedly.

I am glad that every year I am offered the same ESP field. Thus, I can use the materials I have prepared already and don't have to start compiling everything from zero. (Rebecca)

The suggestion by Rebecca, being able to reuse the materials in a situation where there are no suitable coursebooks available, represents the opinion of most interviewees. It also reflects greater help that might reduce their stress level due to unstable working conditions of which some are out of teachers' control (i.e. timetable, group size).

Secondly, the participants expressed the wish to teach the same ESP field every year.

What bothers me the most is the situation where ESP classes contain several disciplines. I understand that these disciplines can be within one field of studies, such as the Humanities [e.g. History, Anthropology, Philosophy] and I also understand there may not be enough students of each discipline to form an ESP group at a particular language level, I still am frustrated by the workload of managing such heterogeneous groups.' (Hannah) 
Finally, the amalgamation of different disciplines within the same ESP group has been widely mentioned as a challenge across the respondent's answers. Given that different students from different fields present different needs, the process of creating a coherent and cohesive curriculum that is able to include a social component among students becomes even more challenging, especially as regards the vocabulary used in each lesson plan. It becomes a balancing act, where the configuration of the exercises and activities used in each class has to aim at achieving very different goals at the same time.

\section{DISCUSSION}

The Didactics of teaching ESP is not yet a part of the teacher training programme for future English teachers in Estonia. Although future English teachers receive a theoretical preparation in the CLIL (Content and Language Integrated Learning) methodologies used in several Estonian lower and upper secondary schools, the ESP teaching methodology has not yet been introduced in the programme. Hence, English teachers working in Tertiary Education are expected to have a high professionalism and aptness to adapt to the students' and to the university's needs. The interviewees expressed the need for continuous in-service training and workshops, which suggest their readiness for professional development. Since teaching ESP courses involves linguistic and grammar elements, as well as group work and presentations, the methodology used for classroom activities related to that content does not differ from other language courses. The need for in-service training mostly concerns the methodology related to specialized terminology and content knowledge. This finding aligns with recommendations for training proposed by Anthony (2018).

The professionalism of ESP teachers is shaped by their readiness to adapt to new professional situations; by how conscious they are about the need for their own professional development; and by which coping strategy they select as a reaction to changes. Hutchinson and Waters (1987) state that coping with the challenges in the field of ESP are related to teacher's knowledge. Teachers with 20 years of teaching experience consider themselves professionals with a high level of self-efficacy. Changes in their work, such as in our case teaching ESP, might need an exercise of reconceptualisation (e.g. change in content, methods and assessment) which would be facilitated by the cooperation with colleagues in a similar situation. Nonetheless, teachers of ESP tend to collaborate more with colleagues they know well, rather than to seek new partners. Based on their stories, they often lack materials dealing with any given subject or content, yet they show minimal initiative to make contact with subject teachers of that particular field. This finding confirms partly Woodrow's (2017) explanation that ESP teachers and subject specialists come from different paradigms and it is hard for them to find a common language for cooperation. Our results reveal a certain passivism to make the first step towards collaboration. On the one hand, ESP teachers are ready to adapt content-based materials to the students' needs, while, on the other hand, they express worries about finding and choosing suitable materials. Furthermore, the cooperation between teachers of the same ESP content usually depends on their personal relationship, rather than on the practical need to collaborate. When they are asked for advice and to share their materials, they are willing to help a colleague, but, in most cases, they do not take the first step themselves. As Hutchinson and Waters highlighted in 1987, there is little cooperation between teachers of ESP and other colleagues, recent studies show that creating an atmosphere with a stronger sense of community and broadening its limits outside the teacher's office might promote collaboration as well as have a positive effect on teachers' job satisfaction (Meristo 2016). 
Universities are big institutions and it may happen that teachers of different disciplines may not know each other personally. Building communities of learning and practice could help them establish a network of professional connections, as the importance of cooperation cannot be underestimated (Norton 2018, Wenger et al. 2002). In addition, creating an atmosphere with a stronger sense of community and broadening its limits outside the teacher's office might promote collaboration as well as have a positive effect on teachers' job satisfaction (Meristo 2016). Stability in teaching ESP courses in Estonian HEI is affected by administrative details. They are hardly ever based on one discipline (as, for example, Law or Psychology), they usually deal with a combination of related disciplines. This situation arises due to the small number of students from a given academic area allocated in each of the ESP groups, combined with the impact of the finiteness of budgetary and human resources that any institution faces. As a result, the amalgamation of academic areas can differ from one year to another. These circumstances, in turn, are a source of stress for ESP teachers. While adapting the course materials to the particular nuances of each group of students is a very common and recommended practice (Hyon 2018, Kithulgoda and Mendis 2020, Noguera-Díaz and PérezParedes 2019, Tomlinson 1998, Woodrow 2017), the variance on the nuance that the yearly recombination of academic disciplines for ESP courses presents is substantially bigger, and, as such, it calls for the constant creation of new materials from scratch, as well as for a long adaptation process, usually involving a thorough retooling, of those materials than can be salvaged from previous courses.

The most direct consequence of this course of action is the decrease of available time that teachers can dedicate to the other responsibilities inherent to the teaching process, such as the personalised attention to students, or the demand of quality in bureaucratic procedures. Furthermore, if the teacher is working for a Higher Education Institution, this constant creation and retooling of materials leads the teacher to an even more lopsided use of their time, usually neglecting the academic research side of the job description, as also highlighted by Lehtonen (2018). This, in turn, might drive them, in the long term, to a slowdown in the pace of their professional advancement, reducing thus the teacher's job satisfaction.

Figure 1 suggests the factors that might help to enhance ESP teacher's perception of job satisfaction. HEI representatives, responsible for organising and managing ESP courses should provide ESP teachers with constant support by offering opportunities for professional development through training and promoting collaborative learning networks. In addition, as this research confirmed, teachers do not take the initiative for establishing collaborative relationships with colleagues. Thus, HEI representatives could introduce and enhance conditions for collaboration between practitioners and subject experts. Last, but not the least, is to offer stable working conditions.

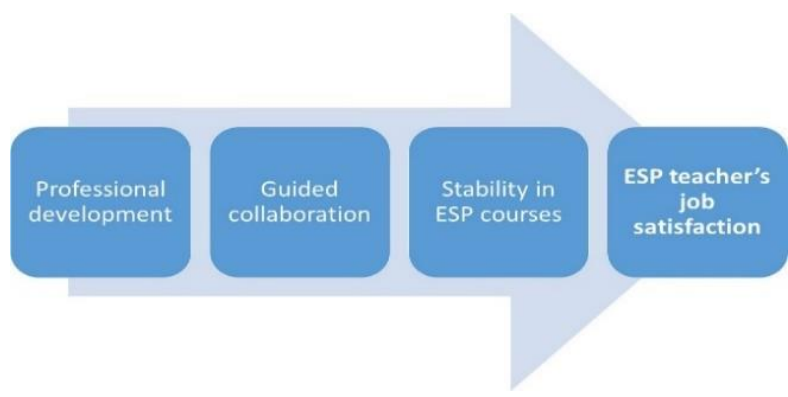

Fig. 1 Factors leading to ESP teacher's job satisfaction 


\section{CONCLUSION}

The purpose of this study was to investigate how ESP teachers with a General English teaching background perceive their work in the field of ESP, to detect the challenges posed by teaching ESP in order to support university ESP teachers working conditions. Three challenges emerged: Professionalism, Cooperation, and Stability. These keywords reflect the actual situation experienced by ESP teachers at Estonian universities. Although the focus of this study is set within the Estonian context, which is relatively recently developed and still finding its optimal configuration, we can see that the results of the present study are in line with what seems to be the universal implications of the uneven development of the ESP field as a whole, more focused on the theoretical side than in resolving the practical obstacles experienced by teachers. Estonian ESP teachers seem to perceive the same problems as their colleagues in other places in the world, such as the lack of ready-made materials, a faulty cooperative environment with subject specialists and other colleagues, the large size of the ESP groups, and constant insecurity about their own knowledge of the specialized target content.

Our research puts forth the idea that, in Estonia, due to the small size of the ESP groups and budgetary concerns, the amalgamation of students from different, seemingly related fields in the same ESP group has indeed become a hurdle to overcome when designing curricula and lesson plans. This is especially true for those teachers who are transitioning to ESP from General English, who have to design their new, own materials from scratch, while experienced ESP teachers can, and often do, resort to adapting their past materials.

However, in order to truly be able to provide a full picture of the Estonian ESP landscape, more research is needed. This study only covers public, state-funded higher education institutes in Estonia, leaving aside the private ones. Given that these privately funded centres have to comply with a different set of legal regulations, there might be a chance for their ESP teaching methodologies to be affected, which, in turn, would have an impact on the teacher's perception of their job. Also, our present study has not taken into account the perceptions of the main protagonist of ESP teaching: the student. It would be necessary to see if the opinions of teachers and students as regards the difficulties and limitations of ESP teaching in Estonia line up in some way, and if so, how and why.

\section{REFERENCES}

Anthony, Laurence. 2018. Introducing English for specific purposes. Routledge.

Arnó-Macià, Elisabet, Marta Aguilar-Pérez, and DietmarTatzl. 2020. "Engineering students' perceptions of the role of ESP courses in internationalized universities." English for Specific Purposes 58: 58-74.

Bahrami, Vahid, Mehrdad Hosseini, and Mahmood Reza Atai. 2019. "Exploring researchinformed practice in English for academic purposes: A narrative study." English for Specific Purposes 54 (2019): 152-165.

Bakić-Mirić, Nataša, and Davronzhon Erkinovich Gaipov. 2015. “The Importance of Teaching Intercultural Communicative Competence in English for Specific Purposes Course in European Medical Schools." Iperstoria 5: 44-50.

Basturkmen, Helen. 2014. Ideas and options in English for specific purposes. Routledge. 
Belcher, Diane D. 2013. "The Future of ESP Research: Resources for Access and Choice.” In The Handbook of English for Specific Purposes, edited by Brian Paltridge and Sue Starfield, 535-551. Chichester: Wiley Blackwell.

Čepon, Slavica. 2016. "Teachers' and Students' Perspectives on the Reasons for Speaking Anxiety in English for Specific Purposes." ESP Today, 4 (2): 84-201.

Charles, Maggie. 2018. "Using Do-It-Yourself Corpora in EAP: A Tailor-Made Resource for Teachers and Students." The Journal of Teaching English for Specific and Academic Purposes 6 (2): 217-224.

Cohen, Louis, Lawrence Manion, and Keith Morrison. 2007. Research Methods in Education (6th edition) London: Routledge.

Coxhead, Averil. 2018. Vocabulary and English for specific purposes research: Quantitative and qualitative perspectives. Routledge.

Ding, Alex, and Gemma Campion. 2016. "EAP teacher development." In The Routledge handbook of English for academic purposes, pp. 571-583. Routledge.

Franceschi, Valeria. 2015. "Nursing Students and the ELF-Aware Syllabus: Exposure to NonENL Accents and Repais Strategies in Coursebooks for Healthcare Professionals." Iperstoria 5: 51-61.

Hall, David R. 2012. "Teacher education for language for specific purposes." The encyclopedia of applied linguistics.

Hutchinson, Tom, and Alan Waters. 1987. English for Specific Purposes: A Learning-centred Approach. Cambridge University Press.

Hyon, Sunny. 2017. Introducing genre and English for specific purposes. Routledge.

Kardaleska, Ljubica, and Gabriela Nedelkoska. 2017. "Teachers as Material Designers Insights from Designing an ESP Course Book (English for Political Science and Diplomacy)." The Journal of Teaching English for Specific and Academic Purposes 5 (3): 545-552.

Kennedy, Brianna L., and Robert Thornberg. 2018. "Deduction, Induction, and Abduction." In The SAGE Handbook of Qualitative Data Collection, edited byUwe Flick, 49-62. London: Sage Publications.

Kim, Jeongyeon, EunGyong Kim, and Soo-Ok Kweon. 2018. "Challenges in implementing English-medium instruction: Perspectives of Humanities and Social Sciences professors teaching engineering students." English for Specific Purposes 51: $111-123$

Kithulgoda, Erandi, and DushyanthiMendis. 2020. "From analysis to pedagogy: Developing ESP materials for the Welcome Address in Sri Lanka." English for Specific Purposes 60: 140-158.

Koltai, Andrea. 2012. "Exploring Student Motivation: Teaching Students Specializing in EU English." Working Papers in Language Pedagogy 6: 46-63.

Laanemaa, Elen. 2015. "Application of CLIL at the Estonian Academy of Securit Sciences." In Vistas of English for Specific Purposes.Chapter Five, edited by NadezdaStojković, 49-59. Newcastle upon Tyne: Cambridge Scholars Publisher.

Lazarus, Richard S. 1993. "Coping Theory and Research: Past, Present, and Future." Psychosomatic Medicine, 55: 234-247.

Lehtonen, Tuula. 2018. "Practitioner research as a way of understanding my work: Making sense of graduates' language use." In Key issues in English for specific purposes in higher education, edited by YaseminKirkgöz and Kenan Dikilitaş, 129140. Springer, Cham. 
Lenard, DraganaBosic, and Ivan Lenard. 2018. "Examining Pedagogical Content Knowledge of ESP teachers." The Journal of Teaching English for Specific and Academic Purposes 6 (3): 353-364. https://doi.org/10.22190/JTESAP1803353B

Leonardi, Vanessa. 2015. "Bridging the Gap Between ESP and CLIL in the University Context." Iperstoria 5: 18-26.

Li, Yongyan, and John Flowerdew. 2020. "Teaching English for Research Publication Purposes (ERPP): A review of language teachers' pedagogical initiatives." English for Specific Purposes 59: 29-41.

Meristo, Merilyn. 2020. "Emotional turmoil or peaceful agreements? A Collective Case Study: Coping with Reforms in Higher Education Institution." Manuscript submitted for publication.

Meristo, Merilyn. 2016. Personal and Contextual Factors Shaping Novice Teachers' early Professional career. Tallinn University. Dissertations on Social Sciences. Tallinn: Tallinn University Press.

Noguera-Díaz, Yolanda, and Pascual Pérez-Paredes. 2019. "Register analysis and ESP pedagogy: Noun-phrase modification in a corpus of English for military navy submariners." English for Specific Purposes 53: 118-130.

Norton, Julie. 2018. "Lesson Study in Higher Education: A Collaborative Vehicle for Professional Learning and Practice Development of Teachers of English for Specific Purposes." In Key issues in English for specific purposes in higher education, edited by YaseminKirkgöz and Kenan Dikilitaş, 95-109. Springer, Cham, 2018.

Paltridge, Brian. 2013. "Chapter 18. Genre and English for Specific Purposes." In The Handbook of English for Specific Purposes, edited by Brian Paltridge and Sue Starfield, 364-384. Chichester: Wiley Blackwell.

Rackevičienė, Sigita, VioletaJanulevičienè, and LiudmilaMockienė. 2019.” English For Specific Purposes and the Second Foreign Language: Reaching Beyond Language Training in BA Philology Study Programme." The Journal of Teaching English for Specific and Academic Purposes 7 (2): 135-146. https://doi.org/10.22190/ JTESAP1902135R

Sears, Jr. Samuel F., Guido G. Jr. Urizar, and Garret D. Evans. 2000. "Examining a Stress Coping-Model of Burnout and Depression in Extension Agents." Journal of Occupational Health Psychology, 5 (1): 56-62.

Stewart, Tim. 2018. "Expanding possibilities for ESP practitioners through interdisciplinary team teaching." In Key issues in English for specific purposes in higher education, edited by YaseminKirkgöz and Kenan Dikilitaş, 141-156. Springer, Cham.

Stojković, Nadezda, NatašaBakić-Mirić, Aleksandra Nikčević-Batrićević, and Nebojša Jotović. 2015. "The Hidden Content in the Syllabus of English for Specific Purposes: Issues of Culture and Globalization." In Vistas of English for Specific Purposes.Chapter Twenty-One, edited by NadezdaStojković, 255-262. Newcastle upon Tyne: Cambridge Scholars Publisher.

Tomlinson, Brian. 1998. Materials Development in Language Teaching. New York: Cambridge University Press.

Tomlinson, Brian. 2020a. "Developing Principled Frameworks for Materials Development." In Developing Materials for Language Teaching, edited by Brian Tomlinson, 95-118. London: Bloomsbury Publishing. 
Tomlinson, Brian. 2020b. Humanizing the Coursebook. In Developing Materials for Language Teaching, edited by Brian Tomlinson, 139-156. London: Bloomsbury Publishing.

Ufier, Alexander. 2015. The Impact of English Language Skills on National Income: A Cross-National Comparison. Federal Deposit Insurance Corporation.

Wenger, Etienne, Richard McDermott, and Williams C. Snyder. 2002. A guide to managing knowledge: Cultivating communities of practice. Boston, MA: Harvard Business School Press.

Woodrow, Lindy. Introducing course design in English for specific purposes. Routledge, 2017. 